\title{
Independent MPP Tracking Method of Hybrid Solar-Wind Power Conditioning Systems Using Integrated Dual-Input Single-PWM-Cell Converter Topology
}

\author{
Daniel Thenathayalan*, Ashraf Ahmed*, Byung-Min Choi*, Jeong-Hyun Park* \\ and Joung-Hu Park ${ }^{\dagger}$
}

\begin{abstract}
This paper proposes the modeling and control strategy to track the MPPs of hybrid PV and Wind power systems, using a new dual input boost converter. The dual input power conditioning system with an independent MPPT control scheme is introduced with minimum number of circuit elements in order to reduce the switching loss, size and cost of the system. Since the operating conditions for the PV and Wind power systems are very distinct from each other, an efficient and superior control system is required to track the MPPs of both renewable sources with the use of a simply-structured single-ended single-inductor converter. The design of Power-Conditioning System (PCS) and detail control strategy are presented in this paper. To provide independent tracking of MPPs, a variable duty-cycle control strategy is employed for the wind system and a variable frequency strategy is employed for the PV system. Finally, the proposed dual-input converter for hybrid power conditioning system is implemented and the hardware test results are presented. From the hardware experiment, it is concluded that the proposed system successfully tracks the MPPs of both of the renewable power systems independently.
\end{abstract}

Keywords: Hybrid renewable power systems, Wind system, PV systems, MPPT

\section{Nomenclature}

$V_{D C} \quad d c$ link voltage

$V_{C} \quad P V$ voltage

$T_{s} \quad$ time period

$A \quad$ Blade area

$V_{r} \quad$ wind speed

$R \quad$ Blade length

$\omega_{m} \quad$ Rotor speed (rpm)

$\lambda \quad$ Air density

$C_{p} \quad$ Power co-efficient

$L=L_{\text {boost }}$ External inductance of the PV boost inductor

$V_{C} \quad P V$ voltage

$D_{0} \quad$ Turn off duty-ratio $\left(D_{0}=1-D_{1}\right.$ in CCM and DCM)

$D_{1} \quad$ Turn-on duty-ratio

$\mathrm{D}_{2} \quad$ Diode-on duty-ratio (in DCM condition)

$I_{L}, \quad$ Inductor current

$f_{s}, \quad$ Switching frequency

$I_{\max }, \quad$ Maximum inductor current

$V_{s}, \quad P V$ source voltage

$I_{s a}, \quad P V$ current

$R_{s a}, \quad P V$ source resistance

$L_{s}, \quad$ Field inductance of the wind generator

$\dagger$ Corresponding Author: Dept. of Electrical Engineering, Soongsil University, Korea. (wait4u@ssu.ac.kr)

* Dept. of Electrical Engineering, Soongsil University, Korea. (\{dany.chellam, bang14feb\}@gmail.com, ashraf_rshwan@yahoo.com, alexander009@naver.com)

Received: July 6, 2016; Accepted: December 12, 2016

$\begin{array}{ll}I_{\text {Wind }}, & \text { Wind generator current } \\ R_{s}, & \text { Internal resistance of the field winding } \\ e_{w}, & \text { Electromotive force of the wind turbine }\end{array}$

\section{Introduction}

In order to meet the increasing energy demand of the century and to secure the earth from increasing pollution due to coal and oil power plants, renewable energy sources are prioritized over non-renewable energy sources and subsidized by most of the government organizations [1-4]. However, the renewable energy systems are not loaded constantly, they are sometimes recommended to be integrated in order to operate the system more efficiently and economically [5-8]. Then, some engineering issues such as high installing cost, complex control structure and inefficient power-conditioning structure of the hybrid-type multiple renewable-energy systems have been emerged. So, integrating not only the sources but also the power conditioning systems has naturally been an issue to obtain a cost-effective, compact and simple control structure.

Renewable energy systems such as PV-Wind systems require solar radiations and kinetic energy to produce electrical energy using solar panels and wind generators. However, solar radiation, wind velocity and wind direction are unpredictable and change rapidly based on the variations of environmental conditions [9-13]. Therefore, 
an individual power conditioning for each of the individual system is required to operate the interconnected renewable systems more efficiently.

Fig. 1 shows the general construction of a PV-wind hybrid renewable-energy system with distributed power conditioning converters. Each of the energy sources in the distributed Power Conditioning System (PCS) is employed with an individual DC-DC converters [5-8].

A simple and cost-effective power conditioning system configuration capable of operating the converter with minimum switching losses is invariably required without compromising on independent control over the maximum power points of the two different sources individually. In order to make the DC-DC converter system more costeffective, compact and efficient along with an ability to operate in the optimal MPPT efficiency, new scheme in both of the converter system and control strategy is required.

As a promising solution, a new power-conditioning technique of the dual-input PV-wind hybrid energy system is proposed in this paper, as shown in Fig. 2. The proposed technique is composed of a single PWM switching cell

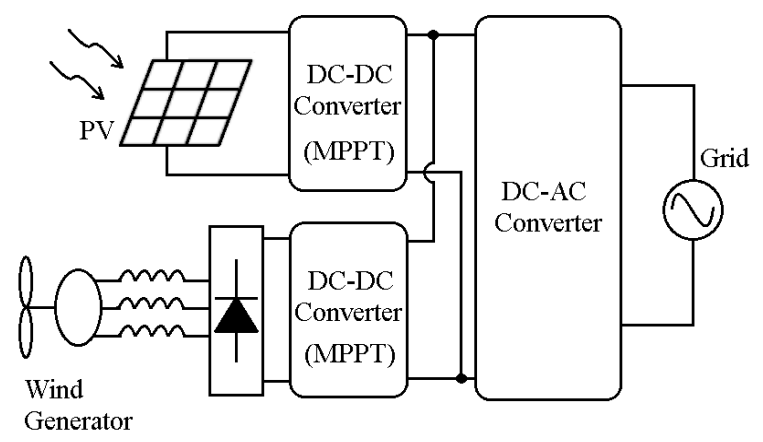

Fig. 1. Construction of a conventional Solar-Wind power conditioning system for independent MPPT control scheme connected to both of the outputs of the PV and wind energy sources in parallel. Definition of the PWM switching cell is a circuit unit which consists of a pair (or more) of switching elements through which the whole power conditioning system is controlled by the complementary operation [21-22]. In proposed scheme, the digital controller senses the voltage and current of the PV and wind sources, and then based on $\mathrm{P} \& \mathrm{O}$ algorithm, the digital controller modulates the duty-cycle and switching frequency of the gate signal for the main switch in the switching cell in order to locate the output voltage $\left(\mathrm{V}_{\mathrm{C}}\right)$ of the PV source and output current $\left(\mathrm{I}_{\text {wind }}\right)$ of the wind generator at each of the MPPs simultaneously. $V_{\text {wind }}$ and $I_{\text {wind }}$ can be used for calculation of the wind power. Since the output voltage of the wind generator is connected in parallel with the PWM switching cell of the boost converter system, the constant DC-link voltage $\left(\mathrm{V}_{\mathrm{dc}}\right)$ can be utilized to calculate the output power of the wind generator instead of the pulsating wind-generator voltage $\left(\mathrm{V}_{\text {wind }}\right)$ as shown by dotted line in Fig. 2. The average wind generator voltage can be precisely estimated by multiplying the DC-link voltage with the turn-off time $\left(\left(1-\mathrm{D}_{1}\right) \mathrm{T}_{\mathrm{s}}=\mathrm{D}_{0} \mathrm{~T}_{\mathrm{s}}\right)$ of the PWM switching cell. The average output power of the wind generator is determined as $\mathrm{P}_{\text {wind }}$ (average) $=\mathrm{D}_{0} \cdot \mathrm{V}_{\mathrm{dc}} \mathrm{I}_{\text {wind }}$ (if ripple is small). Then the MPPT controller unit estimates the voltage $\left(\mathrm{V}_{\mathrm{C}, \text { ref }}\right)$ and current references $\left(\mathrm{I}_{\mathrm{Lwind}}\right.$, ref $)$ for $\mathrm{PV}$ (MPPT controller I) and wind (MPPT controller II) generator systems using $\mathrm{P} \& \mathrm{O}$ algorithm and sends them to the digital compensator unit as shown in Fig. 2. The $\mathrm{PV}$ voltage is controlled through a variable-frequency control whereas the wind generator current is controlled through a variable duty-cycle control. Detailed analysis and design guidelines of the proposed hybrid renewable power conditioning system is presented in the following sections. The paper also presents the feedback-loop controller design of the solar-wind hybrid power conditioning system, and also the results are validated through the

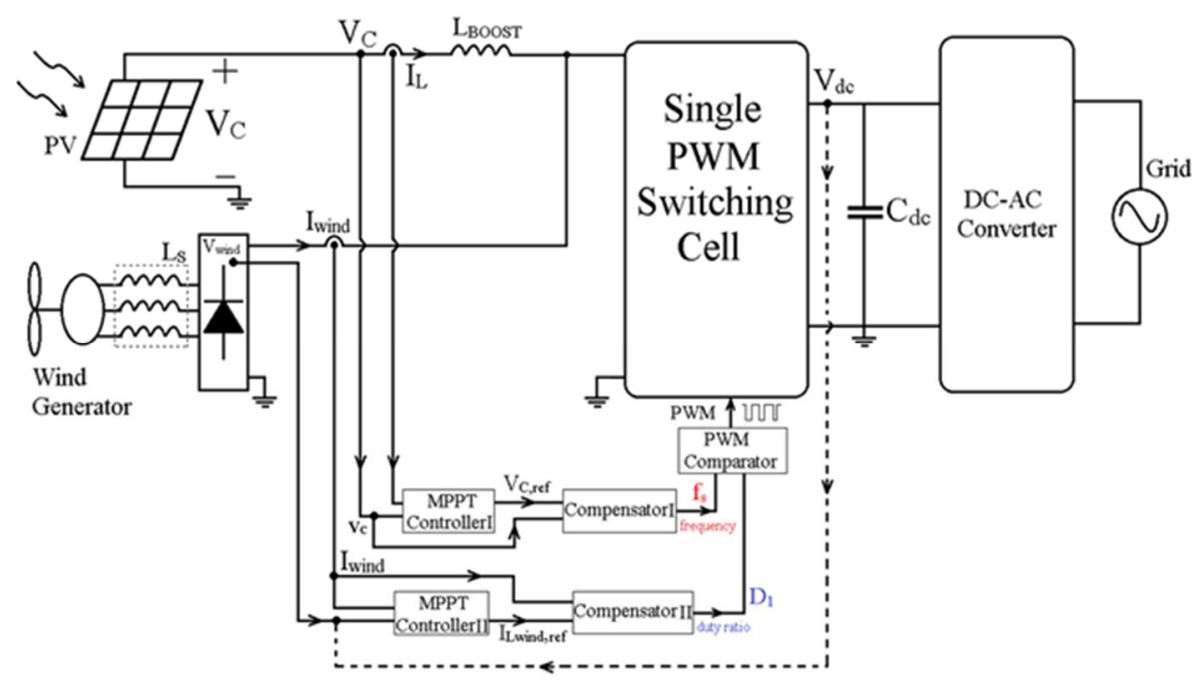

Fig. 2. Control technique of the proposed PCS for hybrid renewable energy system 
hardware implementation of the proposed design. Both of the detailed small-signal modeling of the solar and wind sources are given below in section II.

\section{Proposed Dual Input Single-ended PV-Wind Hybrid Power Conditioning System}

DC-DC converters of a hybrid solar-wind energy system need an efficient power conditioning system to operate the converter efficiently and economically along with the capability to extract the maximum power from each of the renewable energy sources [23-24]. Solar panel and wind generator are distinct in term of the nature of the sources, availability of power and loading factor of the system. The next section introduces a new power conditioning energy system topology and the control achieving both of the costeffectiveness and the high efficiency.

\subsection{Power stage of the proposed dual-input single ended topology}

The power stage of the proposed hybrid solar-wind power conditioning system is shown in Fig. 3. For the successful implementation of a dual-input solar-wind hybrid power conditioning system, a simply-structured single-ended single-inductor (wind side uses the intrinsic inductor of the generator) boost converter topology is proposed in this paper for the individual tracking of MPPs through the simplest power processing schemes.

Then, the system cost, size and converter switching losses can be minimized by the integration of PV-Wind sources using the boost DC-DC Converter. The simplystructured single-ended single external inductor dual input boost converter topology has a single active switch with the gate driver circuitry, almost same as the circuit

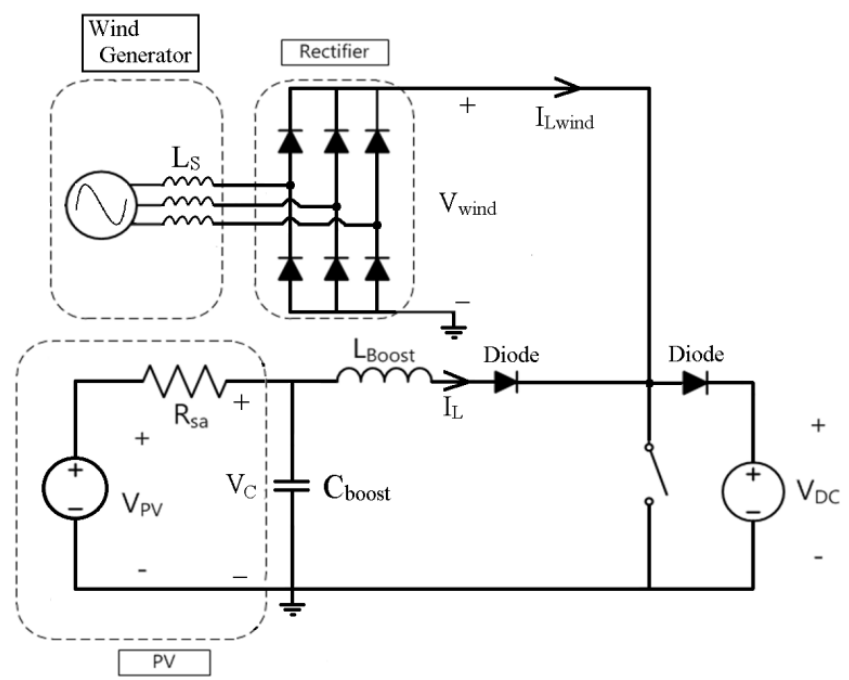

Fig. 3. Hybrid solar-wind power conditioning system with the proposed converter component of a single-sourced power conditioning system. The boost converter configuration can be used to step-up the low input voltage from the sources up to the high DClink voltage. The converter requires one inductor $\left(\mathrm{L}_{\mathrm{BOOST}}\right)$ and a diode to configure a boost operation to track the MPP of the PV system. The boost inductor is chosen to operate under Discontinuous Conduction Mode (DCM) because the PV voltage $\left(\mathrm{V}_{\mathrm{C}}\right)$ is controlled through a variable frequency control method. Whereas, in case of the wind generator system, there is no external inductor or a diode is required because an equivalent inductor offered by the field windings of the wind generator itself can be used for the boost converter operation of the wind power conditioning system [25-26]. Since the equivalent inductor of the wind generator is usually high enough to operate the boost converter in Continuous Conduction Mode (CCM), the output current $\left(\mathrm{I}_{\mathrm{Lwind}}\right)$ of the 3-phase wind rectifier becomes continuous. In this case, the MPP of the wind generator is tracked by perturbing the output current $\left(\mathrm{I}_{\text {Lwind }}\right)$ of the wind generator through a variable duty-cycle control scheme. Therefore, the proposed hybrid system can be built with a single-PWM single-ended topology in a cost and size-competitive hardware structure along with single PWM control scheme. The design of the two-loop feedback controller for the hybrid PV-Wind renewable system is presented in section III and IV in detail.

\subsection{Design consideration}

The MPPT of the photovoltaic power system is controlled by a variable frequency control of boost converter under discontinuous current mode. Therefore, the inductance should be designed small enough to guarantee discontinuous conduction mode in all of the switchingfrequency and duty-cycle ranges. The switching frequency is determined by the digital compensator (compensator-I in Fig. 2) following the MPPT controller in perturb-andobserve (P\&O). The boost inductor can be designed to operate in discontinuous conduction mode based on the analysis using the boost converter model shown in Fig. 4.

From Fig. 4, the voltage transfer gain can be expressed using the turn on $\left(D_{1}\right)$ and turn-off $\left(D_{0}=1-D_{1}\right)$ period of the boost converter using Eq. (1).

$$
\mathrm{V}_{\mathrm{DC}}=\frac{\mathrm{D}_{1}+\mathrm{D}_{0}}{\mathrm{D}_{0}} \mathrm{~V}_{\mathrm{C}}
$$

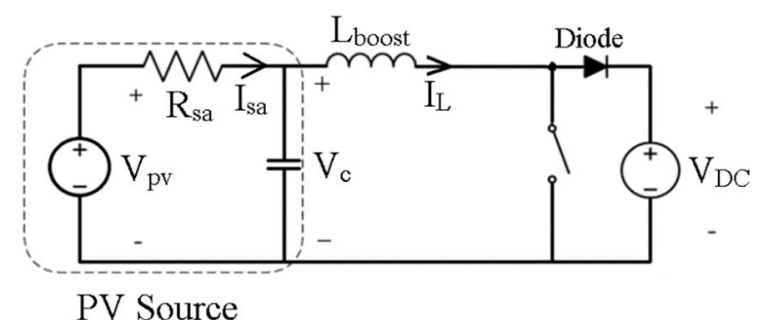

Fig. 4. Boost converter circuit with PV source model 
The peak inductor current of the boost converter, $\mathrm{I}_{\mathrm{P}}$ is

$$
I_{P}=\frac{D_{1} T_{S}}{L} \frac{D_{0}}{D_{1}+D_{0}} V_{D C}
$$

If we consider a boost converter system with an energy conversion efficiency of nearly $100 \%\left(\mathrm{P}_{\text {out }}=\mathrm{P}_{\mathrm{sa}}\right)$, then the equivalent load resistance, $\mathrm{R}_{\mathrm{eq}}$ of the boost converter can be defined by the equation given in Eq. (3)-(4),

$$
\mathrm{R}_{\mathrm{eq}}=\frac{\mathrm{V}_{\mathrm{DC}}{ }^{2}}{\mathrm{P}_{\mathrm{sa}}}
$$

where, $\mathrm{P}_{\mathrm{sa}}$ is the power output of the photovoltaic system and $\mathrm{P}_{\text {out }}$ is the output of boost converter shown in Fig. 4.

$$
\text { Average } \quad \text { load current, } I_{o}=\frac{V_{D C}}{R_{e q}}
$$

The average output current, $I_{o}$ can be defined in terms of peak inductor $\mathrm{I}_{\mathrm{P}}$, current using Eq. (5),

$$
\mathrm{I}_{\mathrm{o}}=\frac{1}{2} \mathrm{D}_{0} \mathrm{I}_{\mathrm{P}}
$$

Combining Eq. (4) and (5), the minimum adequate inductance, $\mathrm{L}_{\mathrm{e}}$ required to operate the boost converter of the PV system in discontinuous current mode can be expresses as Eq. (6),

$$
\mathrm{L}_{\mathrm{e}}=\frac{\mathrm{D}_{1} \mathrm{D}_{0}{ }^{2} \mathrm{R}_{\mathrm{eq}}}{2 \mathrm{f}_{\mathrm{s}}}
$$

The PV boost converter is allowed to operate only under discontinuous current mode to keep the hybrid power conditioning system in stable operating conditions. Therefore, the inductance value, $\mathrm{L}_{\text {boost }}$ must be chosen carefully to keep the boost converter of the PV system in discontinuous conduction mode (DCM) in all the operating regions from light load to full load [27-28]. From Eq. (6), it is seen that the value of the inductor to keep the boost converter in discontinuous current mode also depends on variation in duty ratio (D1), variation in switching frequency of the converter $\left(f_{s}\right)$ and changes in the equivalent load resistance $\left(R_{\text {eq }}\right)$ of the boost converter at different PV power. Therefore, in order to avoid continuous current mode of boost converter under load variations, the inductor value is chosen for the minimum load resistance $\left(R_{\text {eq-min }}\right)$. In other words, if the boost converter of the PV system is designed to operate in discontinuous current mode when delivering the maximum power to the load, it remains in DCM condition under all load conditions. For example, when the operating frequency of the single ended boost converter is $20 \mathrm{kHz}-50 \mathrm{kHz}$, to keep the converter within the discontinuous current conduction mode, the inductor value is designed for the maximum switching frequency $\left(\mathrm{f}_{\mathrm{s}-\max }=50 \mathrm{KHz}\right)$ of the converter.

$$
\frac{\mathrm{d}\left(\mathrm{L}_{\mathrm{e}}\right)}{\mathrm{dD}_{1}}=\frac{\mathrm{d}\left(\mathrm{D}_{1}\left(1-\mathrm{D}_{1}\right)^{2}\right)}{\mathrm{dD}_{1}}=1-4 \mathrm{D}_{1}+3 \mathrm{D}_{1}^{2}
$$

Like load resistance and switching frequency, duty ratio also a parameter which decides the operating modes of a boost converter. The duty ratio that provides the maximum inductor value can be calculated by the differential equations shown in Eq. (7). From Eq. (7), the duty ratio $\left(D_{1}\right)$ required to operate the converter in discontinuous conduction mode at the worst case inductance is 0.66 . With the DCM operation at the duty cycle, it is guaranteed that the converter operates in discontinuous current mode under all other duty-cycle operation. Therefore, the maximum value of the inductor $\mathrm{L}_{\text {boost }}$, should be designed at the worst case conditions such as minimum load resistance, maximum operating frequency and critical duty ratio of 0.66 to keep the converter in discontinues conduction mode at all the operating conditions of the hybrid system [26]. From the selection of an inductance smaller than the boundary one, the digital controller needs only one PWM signal in order to simultaneously regulate both of the outputs of PV and wind systems through dual-input hybrid power conditioning system. The frequency and the duty ratio of the PWM signal are modulated at the same time, which makes the analysis of the dynamic responses and the controller design complicated. It is analyzed in Section III.

An equivalent circuit model of a wind generator is shown in Fig. 5 with an induced back EMF voltage $e_{W}$, in series with an equivalent field winding inductor $\mathrm{L}_{\mathrm{s}}$, field winding resistance, $\mathrm{R}_{\mathrm{w}}$ and an external rectifier diode [2931]. Adding a PWM switching cell forms a boost converter shared with PV system.

$$
\begin{gathered}
\mathrm{T}_{\mathrm{e}}=\frac{\mathrm{P}_{\mathrm{e}}}{\omega_{\mathrm{m}}}=\frac{\mathrm{e}_{\mathrm{w}} \mathrm{i}_{\mathrm{w}}}{\omega_{\mathrm{m}}}=\mathrm{k}_{\mathrm{w}} \mathrm{i}_{\mathrm{w}} \\
\mathrm{e}_{\mathrm{w}}=\mathrm{k}_{\mathrm{w}} \omega_{\mathrm{m}} \\
\mathrm{T}_{\mathrm{m}}=\frac{\mathrm{P}_{\mathrm{wt}}}{\omega_{\mathrm{m}}} \\
\mathrm{P}_{\mathrm{wt}}=\frac{1}{2} \rho \mathrm{AV}_{\mathrm{r}}^{3} \mathrm{C}_{\mathrm{p}}(\lambda, \theta) \\
\lambda=\frac{\omega_{\mathrm{m}} \mathrm{R}}{\mathrm{V}_{\mathrm{s}}}
\end{gathered}
$$

where, $A=\pi R^{2}$ and, $T_{m}=\frac{1}{2} \rho A R V_{r}^{2} \frac{C_{p}(\lambda)}{\lambda}$

Eq. (8) shows the electrical torque $\left(\mathrm{T}_{\mathrm{e}}\right)$ in terms of

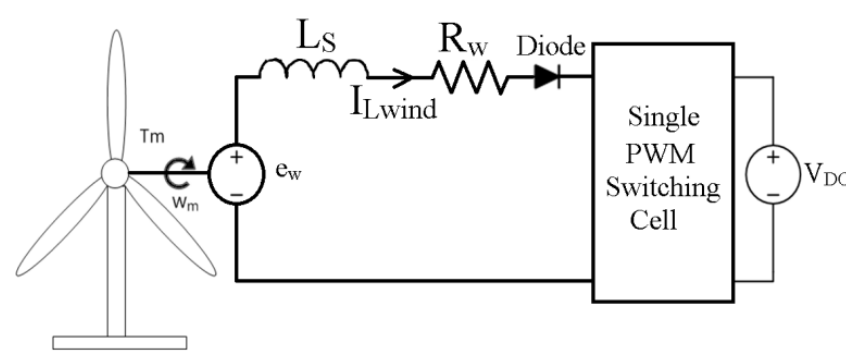

Fig. 5. An equivalent circuit model of a wind generator 
electrical power $\left(\mathrm{P}_{\mathrm{e}}\right)$ and electromotive force $\left(\mathrm{e}_{\mathrm{w}}\right)$. Mechanical torque $\left(\mathrm{T}_{\mathrm{m}}\right)$ and mechanical output power $\left(\mathrm{P}_{\mathrm{wt}}\right)$ of the wind generator are given in terms of Eq. (10) and (11). The mechanical torque and power of the wind generator can be defined using the power coefficient $C_{p}$ using Eq. (12) and (13). The equations can be used to model the wind generator system to validate the proposed converter. Variation of power coefficient for the different air density of wind is defined in Eq. (14).

$$
C_{p}=A_{1} \lambda^{3}+A_{2} \lambda^{2}+A_{3} \lambda+A_{4}
$$

where, $A_{1}, A_{2}, A_{3}$ and $A_{4}$ are the coefficients of $\lambda$.

The detailed construction of the hardware prototype and the wind generator model to realize different operating conditions of the proposed hybrid power conditioning system are explained in experiment section.

In order to generate the maximum power of the hybrid system, the switch and diode of the boost converter should be designed with a power capacity in consideration of the $\mathrm{PV}$ and wind power summation. Hence the generation efficiency can be low when only one of the hybrid operates. The design process in perspective of the power rate for the proposed system is as follows.

The voltage stresses of the switch and diode are the output voltage, same as a simple boost converter.

The current stresses of the switch and diode, $i_{\mathrm{sw}, \mathrm{pk}}$, is the summation of each power source current, derived as:

$$
i_{p k}=\frac{P_{w i n d}}{e_{w}}+\frac{e_{w} D_{1} T_{s}}{2 L_{s}}+\frac{V_{P V} D_{1} T_{s}}{L_{\text {boost }}}
$$

And also, the modified equation can be derived according to the design specification parameters by eliminating $\mathrm{D}_{1}$, such as:

$$
i_{p k}=\frac{P_{w i n d}}{e_{w}}+\frac{e_{w} T_{s}}{2 L_{s}}\left(\frac{M_{w}-1}{M_{w}}\right)+\frac{V_{P v} T_{s}}{L_{b o o s t}} \sqrt{\frac{M_{p v}{ }^{2}-M_{p v}}{K}}
$$

where $\mathrm{M}_{\mathrm{w}}=\mathrm{V}_{\mathrm{DC}} / \mathrm{e}_{\mathrm{w}}, \mathrm{M}_{\mathrm{pv}}=\mathrm{V}_{\mathrm{DC}} / \mathrm{V}_{\mathrm{pv}}, \mathrm{P}_{\text {wind }}$ is the maximum wind power, $\mathrm{K}=\mathrm{RT}_{\mathrm{s}} / 2 \mathrm{~L}$.

From the voltage and current stresses, the switching device can be selected.

The overall controller design considerations are as follows.

In Fig. 6(a), the wind power controller is shown. The parameter $\mathrm{V}_{\text {out }}$ means the boost output voltage and $\mathrm{I}_{\text {sen }}$ means the rectified wind current. The wind MPPT controller receives the wind voltage and current simultaneously, and gives a current reference $i_{\text {ref }}$ to the wind current feedback control loop. Then, a PI compensator $(\mathrm{H}(\mathrm{s}))$ controls the wind current through the negative feedback operation. In Fig. 6(b), a controller block diagram of the PV power system is presented. MPPT2 module is the PV MPPT controller which receives the PV voltage $\left(\mathrm{V}_{\mathrm{pv}_{-} \text {sen }}\right)$ and current $\left(\mathrm{I}_{\mathrm{pv}_{-} \text {sen }}\right)$, making the $\mathrm{PV}$ voltage

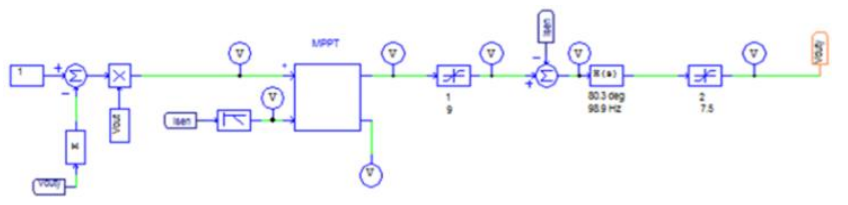

(a) Controller block diagram of the wind power system

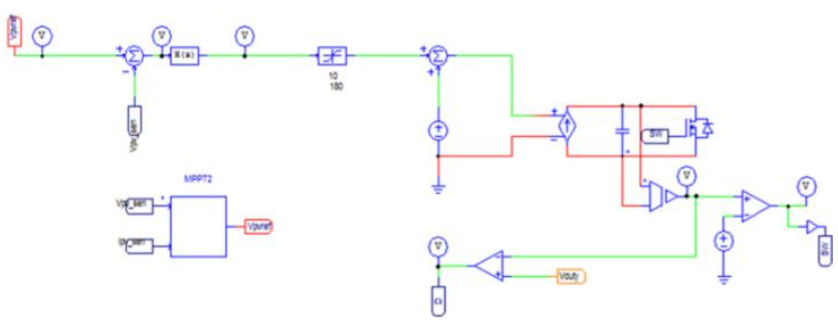

(b) controller block diagram of the photovoltaic power system

Fig. 6. Control configuration of the PV-wind hybrid power conditioning system

reference $\left(\mathrm{V}_{\mathrm{pv}, \mathrm{ref}}\right)$ for the voltage feedback loop. Then, a PI compensator $(\mathrm{H}(\mathrm{s}))$ controls the $\mathrm{PV}$ voltage through a switching frequency variation. The variation is made by a triangle slope control which uses a variable current source adjusted by the compensator output. When a triangle reaches a level, a comparator reset a capacitor which stores the charges of the current source. The triangle gives no influence on the duty cycle, so the wind controller and PV one can work independently. Actually, the controller is a digital signal processor in real hardware, so the figures were implemented in $\mathrm{C}$ code.

\section{Small Signal Modeling}

\subsection{PV system}

The dynamic characteristic modeling of the PV system is carried out to design a stable frequency-control loop under a discontinuous conduction mode. In the feedback control configuration, the voltage and current information of the PV system are sent to digital controller and the system is regulated to deliver the maximum output power using a perturb-and-observe control algorithm [14-16]. The control structure of the photovoltaic system using digital controller is shown in Fig. 7. In order to the design the variablefrequency control loop for the PV system, the control (frequency)-to-PV-voltage transfer function should be derived. In this section, the PV source connected to a boost converter is analyzed using state-space averaging technique and the control-to-PV voltage transfer function is derived through the linearization process under small-signal assumption.

The small signal modeling of the PV system is derived in Appendix section and the final control-to-PV voltage transfer function is given in (A.25). The control (switching 


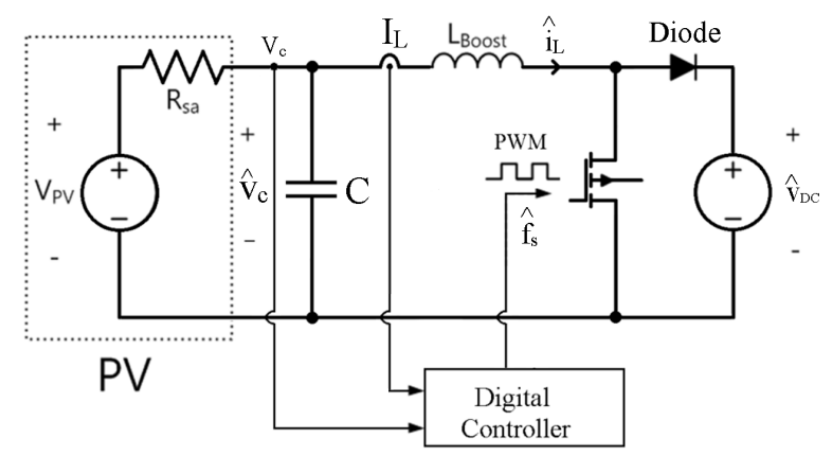

Fig. 7. Control structure of the PV system

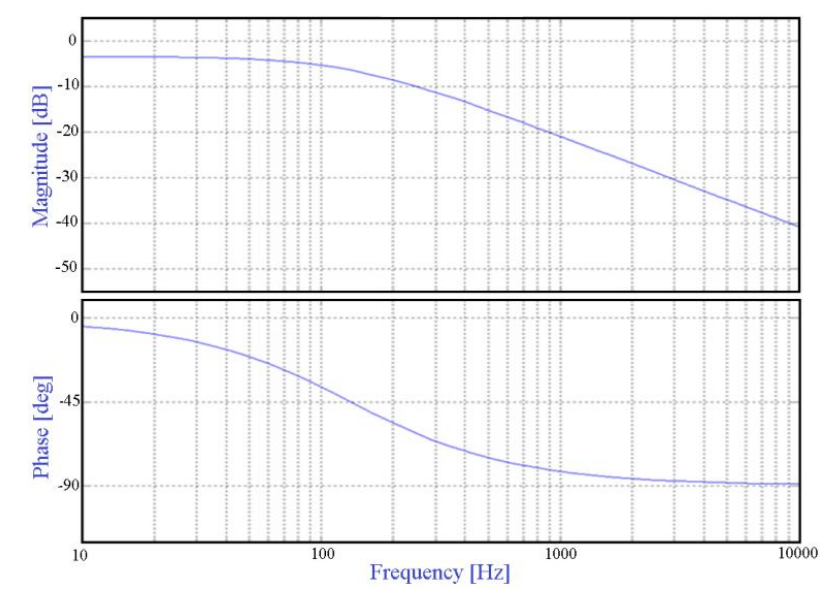

Fig. 8. Bode plot of the control-to-PV voltage transfer function of PV system

frequency) to PV voltage transfer function of the boost converter is presented in Eq. (17). Fig. 8 shows the bode plot of the control-to-PV voltage transfer function of $\mathrm{PV}$ system using the mathematical model shown in Eq. (17).

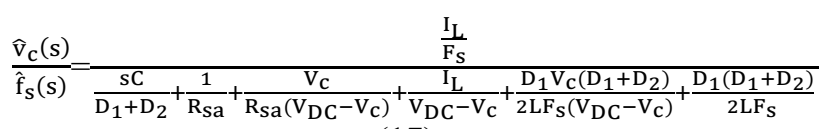

(17)

\subsection{Wind generator}

The electrical output power of the wind generator is optimized and controlled through a variable duty-cycle control method by operating the boost converter in continuous conduction mode thanks to the high inductance of the field windings from the wind generator. The continuous output current of the wind generator and the DC link voltage are sent to the digital controller and the system is regulated to deliver the maximum output power using perturb-and-observe control algorithm. The control structure of the wind power generator is shown in Fig. 9. In this section, the wind generator model connected to the PWM switching cell of the hybrid power conditioning system is analyzed.

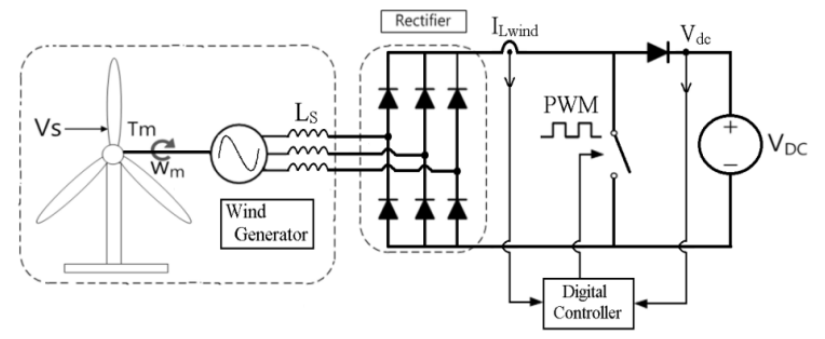

Fig. 9. Control structure of the wind generator model

The small signal modeling of the wind system is derived in Appendix section and the final control-to-wind generator current transfer function is given in (A.36). The control (duty cycle) to wind generator current transfer function of the boost converter is presented in Eq. (18),

$$
\mathrm{G}_{\mathrm{W}}=\frac{\hat{\mathrm{t}}_{\mathrm{W}}(\mathrm{s})}{\hat{\mathrm{d}}_{1}(\mathrm{~s})}=\frac{\mathrm{V}_{\mathrm{DC}}}{\mathrm{sL_{ \textrm {s } }}+\mathrm{R}_{\mathrm{s}}}
$$

\section{Transient Analysis}

The entire control configuration of the hybrid solar-wind renewable energy system is shown in Fig. 10. The thick solid lines mean the feedback controller gain of the integrated PV-wind system, whereas the dotted lines show the open-loop transfer characteristics of the hybrid power plant. The combined structure shows how the total system is controlled through the variable frequency and variable duty-cycle control-parameters under a dynamical crosstalk $\left(\mathrm{G}_{\mathrm{dpv}}\right)$ between them.

The relationship between each of the control variables of Fig. 10 can be expressed as,

$$
\widehat{\mathrm{V}}_{\mathrm{C}}=\widehat{\mathrm{V}}_{\mathrm{C}}\left(-\mathrm{T}_{\mathrm{pv}}\right)+\mathrm{G}_{\mathrm{dpv}} \widehat{\mathrm{d}}_{1}+\mathrm{G}_{\mathrm{dclink}} \widehat{\mathrm{V}}_{\mathrm{DC}}
$$

where, $\widehat{\mathrm{d}}_{1}=-\mathrm{H}_{\mathrm{w}}\left(\mathrm{G}_{\mathrm{dpv}} \widehat{\mathrm{V}}_{\mathrm{DC}}+\mathrm{G}_{\mathrm{w}} \widehat{\mathrm{d}}_{1}\right)$.

And also,

$$
\left(1+\mathrm{T}_{\mathrm{w}}\right) \widehat{\mathrm{d}}_{1}=-\mathrm{H}_{\mathrm{w}} \mathrm{G}_{\mathrm{dw}} \widehat{\mathrm{V}}_{\mathrm{DC}}
$$

by substituting Eq. (20) into Eq. (19),

$$
\left(1+T_{p v}\right) \widehat{V}_{C}=\frac{-H_{w} G_{d p v} G_{d w}}{1+T_{w}} \widehat{V}_{D C}+G_{d c l i n k} \widehat{V}_{D C} .
$$

After arranging the terms,

$$
\frac{\widehat{V}_{C}}{\widehat{V}_{D C}}=\frac{-H_{W} G_{d p v} G_{d w}+G_{d c l i n k}\left(1+T_{W}\right)}{\left(1+T_{p v}\right)\left(1+T_{w}\right)}
$$

Eq. (22) shows the closed-loop transfer function of the DC-link-voltage-to-PV voltage. Using the control block diagram shown in Fig. 10, the loop gain characteristic transfer function of the entire hybrid power conditioning system can be expressed by the Eq. (23), 


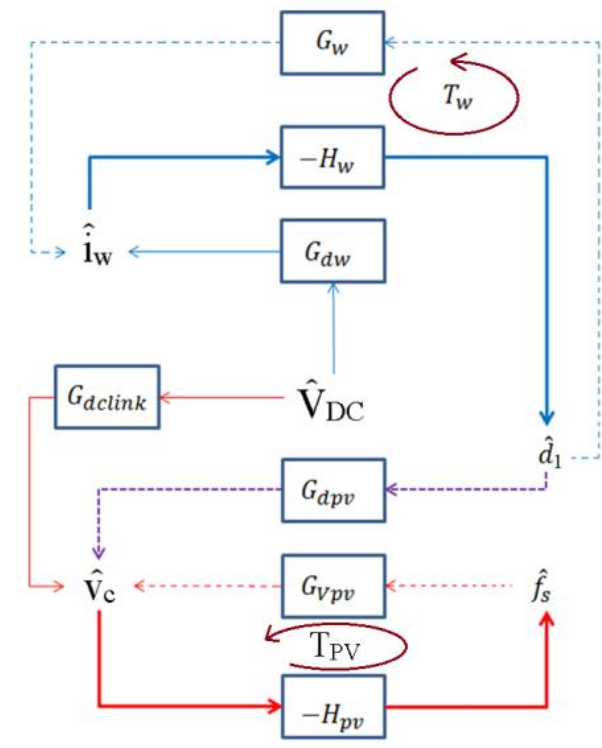

Fig. 10. Control block-diagram of the hybrid solar-wind renewable energy system

$$
\mathrm{T}_{\text {char }}=\mathrm{T}_{\mathrm{w}}+\mathrm{T}_{\mathrm{pv}}+\mathrm{T}_{\mathrm{w}} \mathrm{T}_{\mathrm{pv}}
$$

A stable and effective control operation for the hybrid renewable energy power conditioning system depends on the design of each of the closed loop transfer functions of wind and PV systems $\left(\mathrm{T}_{\mathrm{PV}}, \mathrm{T}_{\mathrm{W}}\right)$. The characteristic loopgain function $\left(\mathrm{T}_{\text {char }}\right)$ of the hybrid control system is given in Eq. (23). From the equation, it can be seen that the stability of the hybrid system is related to the design factors of the loop-gain of the individual systems such as the wind PCS and the PV one. Among the terms, product term of the wind and the PV loop gain, $\mathrm{T}_{\mathrm{w}} \mathrm{T}_{\mathrm{pv}}$, clearly shows that there is an interaction between the two individual systems. In order to guarantee the hybrid system operate in stable responses, all the loop gains such as PV $\left(T_{P V}\right)$, wind $\left(T_{W}\right)$ and the entire hybrid system $\left(T_{\text {char }}\right)$ are required to be in stable criteria. The individual system loop $\left(\mathrm{T}_{\mathrm{PV}}, \mathrm{T}_{\mathrm{W}}\right)$ design procedures are conventional and straightforward [7, 28].

However, the hybrid loop gain $\left(\mathrm{T}_{\text {char }}\right)$ is quite complicated since the product term $\left(\mathrm{T}_{\mathrm{w}} \mathrm{T}_{\mathrm{pv}}\right)$ in the total loop gain leads the gain to very different features of the bandwidth and the stability from the single loop gains. In this paper, for the intuitive controller design, loop gains of the PV and wind systems are designed for the bandwidth to be located far from each other to reduce the effect of interference in the total loop gain. Then, the gain of $T_{w} T_{p v}$ becomes relatively small to the other terms around the bandwidth frequency of the total loop, so the phase and gain margins of the control loop, $\mathrm{T}_{\text {char }}$ can be almost the same as those of the stable loop of the PV or wind. In this paper, the bandwidth of the PV system loop gain is designed to be 10 times greater than that of the wind control loop-gain in order to separately design the PV and wind feedback-loop controller with negligible interference
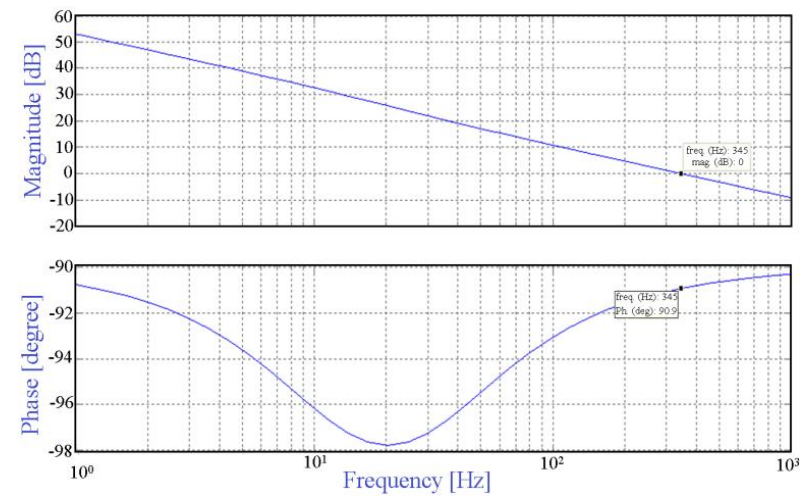

Fig. 11. Loop gain of the PV system (Tpv). The bandwidth frequency is $345 \mathrm{~Hz}$ and phase margin 84.3 degree.

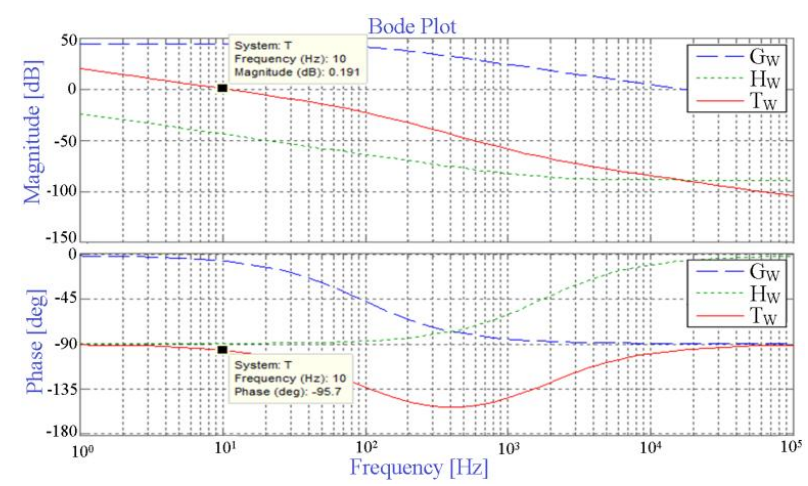

$\mathrm{G}_{\mathrm{W}}$, duty-to-wind generator current transfer function $\left(\frac{\hat{\mathrm{w}}_{\mathrm{W}}(\mathrm{s})}{\widehat{\mathrm{d}}(\mathrm{s})}\right) \cdot \mathrm{H}_{\mathrm{W}}=$ compensator transfer function, $\mathrm{T}_{\mathrm{W}}=$ closed loop transfer functions of the wind generator system bandwidth frequency, $10 \mathrm{~Hz}$ and phase margin 90.9 degree

Fig. 12. Bode plot transfer functions of the wind system

between them.

Examples of the PV and wind controllers' design results are shown in Fig. $11\left(\mathrm{~T}_{\mathrm{PV}}\right)$ and Fig. $12\left(\mathrm{~T}_{\mathrm{W}}\right)$, respectively. It can be seen from the bode plots that the bandwidth frequencies of the PV and wind generator systems are designed with an adequate separation from each other at the frequencies of $10 \mathrm{~Hz}$ and $345 \mathrm{~Hz}$ for wind and PV system respectively. The dynamic interaction between the two control loops can be effectively reduced by providing enough separation between them on the frequency domain.

\section{Hardware Result}

In order to prove the validity of the proposed simplystructured single-ended single-inductor hybrid power conditioning system, the dual-power hardware prototype was implemented. The construction of the hardware prototype is shown in Fig. 13. The key parameters of the PV boost converter and wind generator are presented in Table 1 and 2. 
Table 1. Parameters of the PV source and the converter

\begin{tabular}{c|c}
\hline MPP Voltage Range & $28 \mathrm{~V}-42 \mathrm{~V}$ \\
\hline $\mathrm{V}_{\mathrm{DC}}$ & $200 \mathrm{~V}$ \\
\hline $\mathrm{R}_{\text {sa boost }}$ & $26.5 \Omega$ \\
\hline $\mathrm{L}_{\text {boost }}$ & $62 \mathrm{uH}$ \\
\hline $\mathrm{C}_{\text {boost }}$ & $680 \mathrm{uF}$ \\
\hline
\end{tabular}

Table 2. Design parameters of the wind simulator

\begin{tabular}{c|c|c}
\hline Parameter & Symbol & Value \\
\hline Wind Velocity & $\mathrm{V}_{\mathrm{r}}$ & $8-12[\mathrm{~m} / \mathrm{s}]$ \\
\hline Blade Length & $\mathrm{R}$ & $1.1[\mathrm{~m}]$ \\
\hline Lambda-3 co-efficient & $\mathrm{A}_{1}$ & -0.0016 \\
\hline Lambda-2 co-efficient & $\mathrm{A}_{2}$ & 0.017 \\
\hline Lambda-1 co-efficient & $\mathrm{A}_{3}$ & 0.025 \\
\hline Lambda-0 co-efficient & $\mathrm{A}_{4}$ & -0.078 \\
\hline Air Density & $\rho$ & $1 \mathrm{~kg} / \mathrm{m}^{3}$ \\
\hline Turbine Speed & $\omega_{\mathrm{m}}$ & $0 \sim 1300 \mathrm{rpm}$ \\
\hline
\end{tabular}

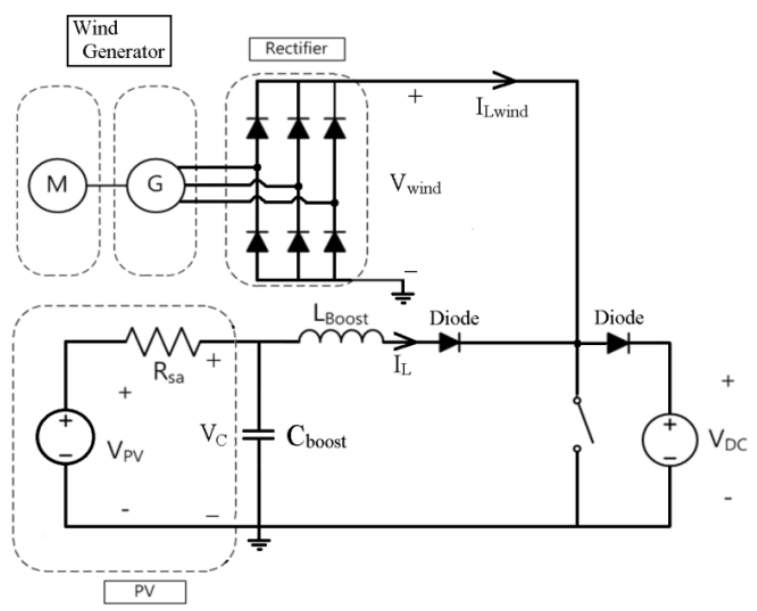

Fig. 13. Experimental setup of the proposed hardware prototype

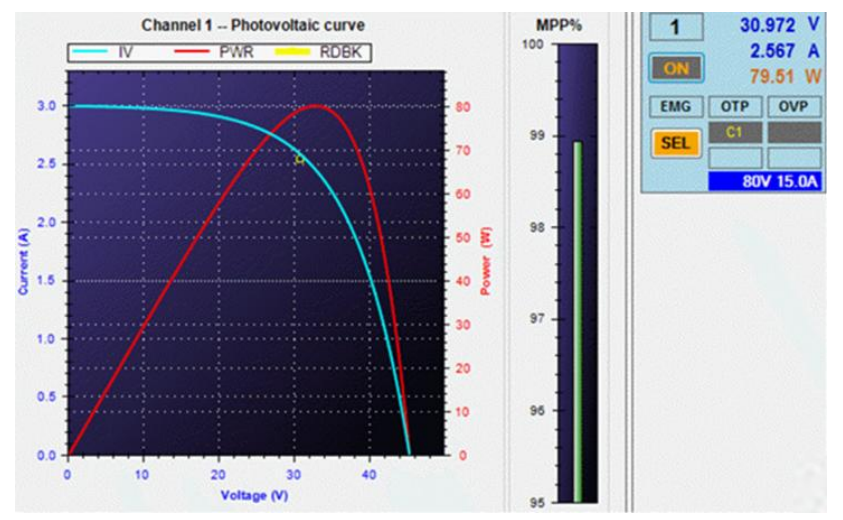

Fig. 14. V-I and V-P characteristic curves of the PV system under a particular radiation and the MPPT efficiency status bar

A PV-array simulator (TerraSAS) and a motor-generator (M-G) coupled wind simulator are used to demonstrate the electrical characteristics of the hybrid PV-Solar renewable

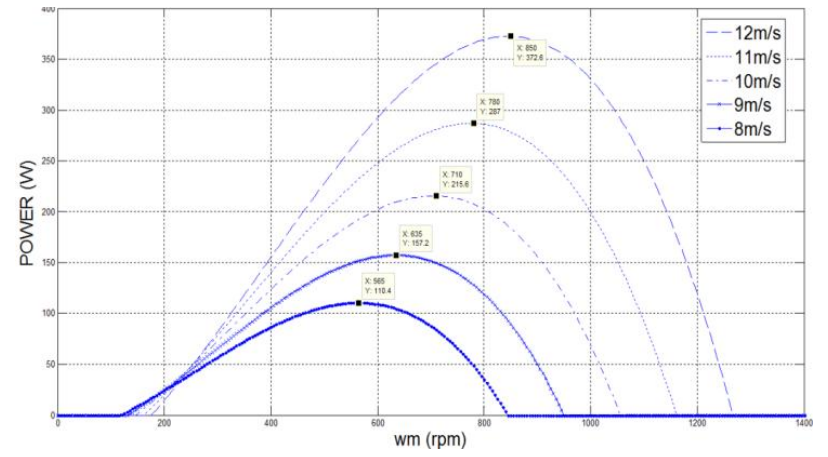

Fig. 15. Maximum power point of the wind generator at different wind and turbine speed

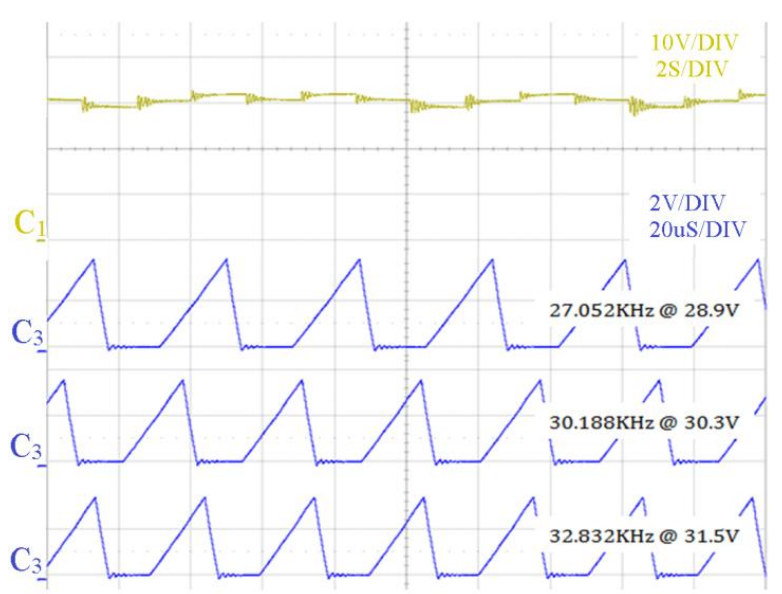

Fig. 16. Key waveforms of the PV boost converter, the MPPT voltage is $30 \mathrm{~V}$ (The PV voltage (C1) and the inductor current waveforms (C2) at each of the voltage steps)

energy sources as shown in Fig. 13. The V-I characteristic of the PV-module used to validate the proposed power conditioning system is shown in Fig. 14. The output DClink voltage is set to $200 \mathrm{~V}$. The boost-inductor $\mathrm{L}_{\text {boost }}$ is designed to be $62 \mathrm{uH}$ to operate the PV boost under DCM in all the operating conditions. In order to realize the operating conditions of a wind generator, an M-G set was utilized. The Maximum Power Points (MPP) of the wind simulator at different wind and turbine speed are plotted in Fig. 15. By varying the speed of an electric motor of the M-G set, the different MPP conditions can be realized.

For the performance validation of each power-system, individual power conditioning system was implemented and tested. The test result of the PV voltage $\left(\mathrm{V}_{\mathrm{C}}\right)$ of the independent PV system when operating at MPPT voltage of $30.3 \mathrm{~V}$ is shown in Fig. 16. The instantaneous PVvoltage is perturbed between $28.9 \mathrm{~V}$ and $31.5 \mathrm{~V}$ to keep the output power of PV panel at the MPP. The DCM inductor current waveforms at each of the voltage steps are also shown in Fig. 16. It can be seen that the switching frequency also varies from $27.05 \mathrm{KHz}$ to $32.83 \mathrm{KHz}$ according to the voltage levels. 


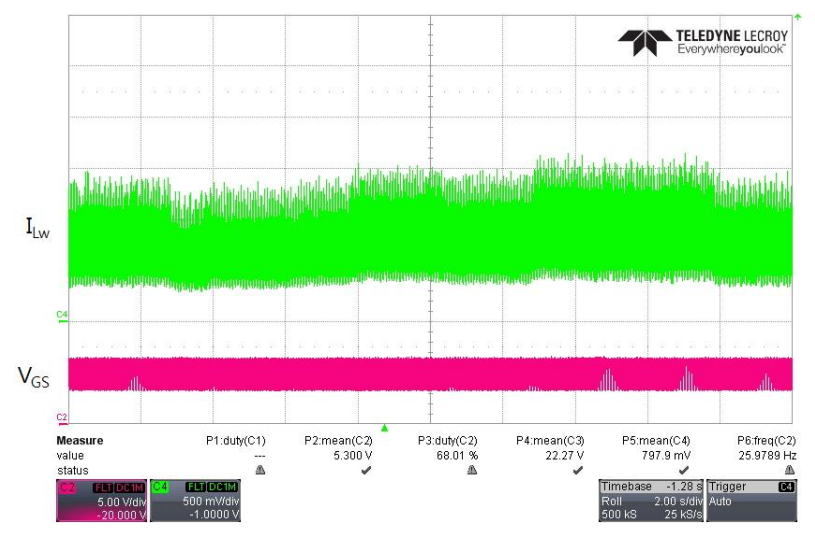

Fig. 17. The voltage (Vwind) and current (Iwind) waveforms of the independent wind generator system at the wind speed of $11 \mathrm{~m} / \mathrm{sec}$

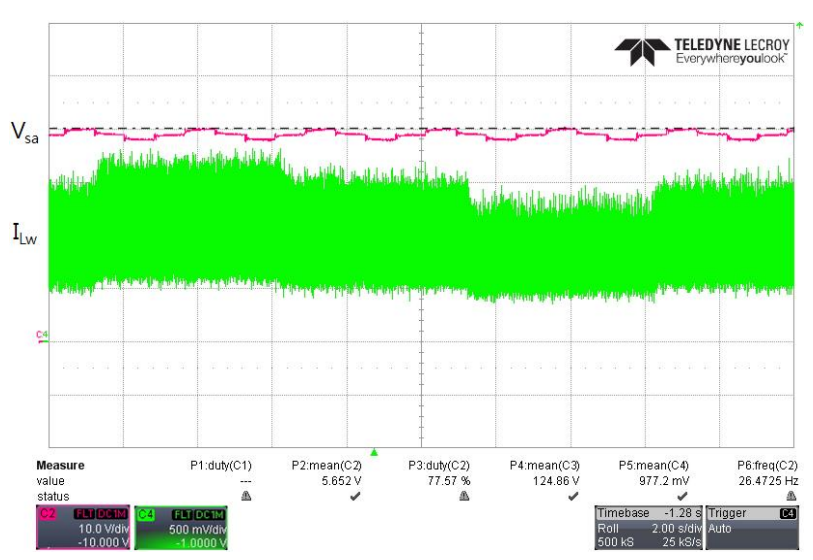

Fig. 18. MPPT key waveforms $\left(\mathrm{V}_{\mathrm{C}}\right.$ and $\left.\mathrm{I}_{\text {wind }}\right)$ of PV-Wind hybrid renewable energy system

Fig. 17 shows the output current waveform of the wind generator under an independent operation of the wind power system without PV operation. The wind speed was set to be at $11 \mathrm{~m} / \mathrm{sec}$. The figure proves that the internal inductors of the wind PCS operates in continuous conduction mode. The average current mode controller of the wind generator controls well the current around the 1-A MPP by duty cycle adjustment to draw the maximum output power from the generator as shown in Fig. 17. From the figure, it can be seen that using $\mathrm{P} \& \mathrm{O}$ algorithm, the wind generator system tracks the MPPT range successfully.

Finally, in Fig. 18, the MPPT key waveforms of the proposed hybrid Solar-Wind single-ended single-inductor DC-DC converter connected to a single PWM switching cell is presented. The MPPT voltage reference for PV system is set to be $39 \mathrm{~V}$ and the MPPT current reference for wind generator system is set to be 1 A. From Fig. 18, it can be seen that the proposed single-PWM operated single switching-cell converter can successfully track the MPPT voltage and MPPT current of the hybrid solar-wind power system simultaneously using P\&O algorithm.

The trade-off of the proposed scheme is the power
Table 3. Key parameters and the component list of the hardware prototype for efficiency measurement

\begin{tabular}{c|c}
\hline Vc & $29-41[\mathrm{~V}]$ \\
\hline $\mathrm{L}_{\text {Boost }}$ & $62[\mathrm{uH}]$ \\
\hline $\mathrm{C}_{\text {boost }}$ & $680[\mathrm{uF}]$ \\
\hline $\mathrm{V}_{\mathrm{DC}}$ & $200[\mathrm{~V}]$ \\
\hline PV diode & MBR40250 \\
\hline Boost diode & MBRF20200CTG \\
\hline MOSFET & IRFP4868 \\
\hline
\end{tabular}

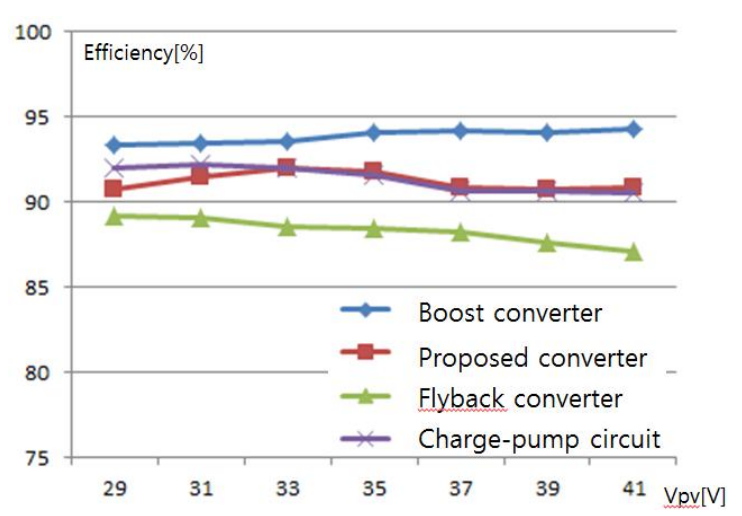

Fig. 19. The efficiency comparison of the hardware prototype of the PV power conditioning system

efficiency. The power flow path from PV and wind to the load is exactly the same between the proposed and the conventional ones except the extra diode in series with $\mathrm{L}_{\text {Boost. }}$ The proposed scheme should consider the power loss in the diode conduction. So, the authors newly measured the efficiency of the PV power conditioning system. Below is the result. Table III inserted in manuscript revision shows the part number list and the key parameters of the hardware prototype. The efficiency graphs of the hardware prototype according to the input voltage variations are presented in Fig. 19. From the figure, it can be seen that the proposed converter has the maximum efficiency of $92 \%$, which is very high even though the value is slightly lower by around $2 \%$ than the conventional boost-converter power conditioning system. The other two conventional topology, such as flyback and flyback charge-pump [32] converters have lower efficiencies than that of the boost converter in conventional separate power conditioning converter architecture as shown in the figure.

\section{Conclusion}

The output power of a renewable energy sources such as wind and solar systems varies over the weather and climate conditions. Because of the reason, a hybrid renewable power conditioning system with the ability to control each of the sources independently to provide stable power production with a high energy-conversion efficiency is required. In this paper, a new hybrid power conditioning 
system with dual-sourced single-inductor single PWMswitching-cell converter is proposed. A new frequency and duty-cycle hybrid control technique has also been introduced to simultaneously operate the proposed system at the corresponding MPPs using $\mathrm{P} \& \mathrm{O}$ algorithm with minimum number of switching elements. The small signal analysis of the boost converter with PV and wind systems is presented. Guidelines to design a stable MPPT control loop for the proposed single ended $\mathrm{PV}$-wind renewable power condition system is also presented. Finally, the system and control techniques are validated through the hardware implementation. The results prove that the system successfully provide an individual MPPT control to each of the renewable energy sources operating at different power levels with reduced switching devices as well as the single gate drivers for the cost and size effectiveness.

\section{Appendix}

\section{A. Small signal modeling of PV boost converter}

When the switch is closed (DCM mode-I operation), the voltage-second balance equation of the boost inductor can be expressed as eq. (A.1) using the small-signal PWM circuit of the boost converter in Fig. A.1.

$$
\mathrm{L} \frac{\mathrm{dI}_{\mathrm{L}}}{\mathrm{dt}}=\mathrm{v}_{\mathrm{c}}
$$

When the switch is open (DCM mode-II operation), the voltage second balance for the boost converter becomes,

$$
\mathrm{L} \frac{\mathrm{di}_{\mathrm{L}}}{\mathrm{dt}}=\mathrm{v}_{\mathrm{c}}-\mathrm{V}_{\mathrm{DC}}
$$

Applying state-space averaging technique to (A.1), (A.2)

$$
\mathrm{L} \frac{\mathrm{di}_{\mathrm{L}}}{\mathrm{dt}}=\mathrm{v}_{\mathrm{C}} \mathrm{D}_{1}+\left(\mathrm{v}_{\mathrm{C}}-\mathrm{V}_{\mathrm{DC}}\right) \mathrm{d}_{2}
$$

Small signal perturbation to all the control terms,

$$
\begin{aligned}
\mathrm{i}_{\mathrm{L}} & =\mathrm{I}_{\mathrm{L}}+\hat{\mathrm{l}}_{\mathrm{L}} \\
\mathrm{v}_{\mathrm{c}} & =\mathrm{V}_{\mathrm{c}}+\hat{\mathrm{v}}_{\mathrm{c}} \\
\mathrm{d}_{2} & =\mathrm{D}_{2}+\hat{\mathrm{d}}_{2}
\end{aligned}
$$

Applying small signal linearization process to eq. (A.3),

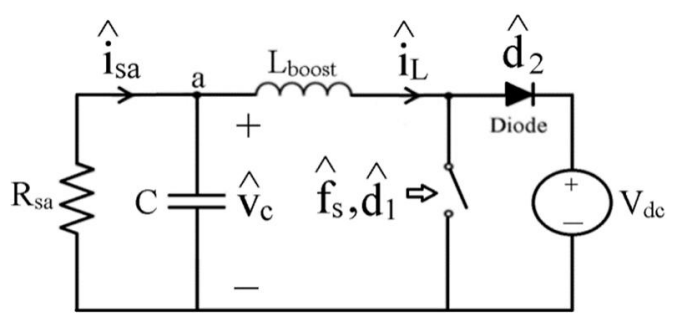

Fig. A.1. small-signal PWM circuit of boost converter

$$
L \frac{d\left(I_{L}+\hat{i}_{L}\right)}{d t}=\left(V_{c}+\hat{v}_{c}\right) D_{1}+\left(\left(V_{c}+\hat{v}_{c}\right)-V_{D C}\right)\left(D_{2}+\hat{d}_{2}\right)
$$

By Laplace transform,

$$
s L \hat{\imath}_{L}(s)=D_{1} \hat{v}_{c}(s)+D_{2} \hat{v}_{c}(s)+\left(V_{c}-V_{D C}\right) \hat{d}_{2}(s)
$$

In case of DCM operation, the average inductor current $\hat{\imath}_{\mathrm{L}}(\mathrm{s})=0$, therefore eq. (A.8) becomes,

$$
\widehat{\mathrm{d}}_{2}(\mathrm{~s})=\frac{\mathrm{D}_{1}+\mathrm{D}_{2}}{\mathrm{~V}_{\mathrm{DC}}-\mathrm{V}_{\mathrm{C}}} \hat{\mathrm{v}}_{\mathrm{c}}(\mathrm{s})
$$

The average inductor current $i_{L}$ is,

$$
\mathrm{i}_{\mathrm{L}}=\frac{1}{\mathrm{~T}_{\mathrm{s}}} \frac{1}{2} \mathrm{i}_{\max }\left(\mathrm{D}_{1}+\mathrm{d}_{2}\right) \mathrm{T}_{\mathrm{S}}
$$

From Eq. (1) - Eq. (5),

$$
\begin{gathered}
\mathrm{i}_{\max }=\frac{\mathrm{v}_{\mathrm{c}} \mathrm{D}_{1} \mathrm{~T}_{\mathrm{S}}}{\mathrm{L}} \\
\mathrm{i}_{\mathrm{L}}=\frac{\mathrm{v}_{\mathrm{c}} \mathrm{D}_{1}\left(\mathrm{D}_{1}+\mathrm{d}_{2}\right)}{2 \mathrm{Lf}_{\mathrm{S}}} \\
\mathrm{f}_{\mathrm{S}} \mathrm{i}_{\mathrm{L}}=\frac{\mathrm{v}_{\mathrm{C}} \mathrm{D}_{1}\left(\mathrm{D}_{1}+\mathrm{d}_{2}\right)}{2 \mathrm{~L}}
\end{gathered}
$$

Applying small signal Perturbation,

$$
\mathrm{F}_{\mathrm{s}}=\mathrm{F}_{\mathrm{s}}+\hat{\mathrm{f}}_{\mathrm{s}}(\mathrm{s})
$$

Applying state space averaging technique to equation (A.13)

$$
\begin{aligned}
& \left(\mathrm{F}_{\mathrm{s}}+\hat{\mathrm{f}}_{\mathrm{s}}(\mathrm{s})\right)\left(\mathrm{I}_{\mathrm{L}}+\hat{\mathrm{l}}_{\mathrm{L}}(\mathrm{s})=\right. \\
& \quad \frac{\mathrm{D}_{1}}{2 \mathrm{~L}}\left(\mathrm{~V}_{\mathrm{c}}+\hat{\mathrm{v}}_{\mathrm{c}}(\mathrm{s})\right)\left(\mathrm{D}_{1}+\mathrm{D}_{2}+\hat{\mathrm{d}}_{2}(\mathrm{~s})\right)
\end{aligned}
$$

By simplification,

$$
\begin{aligned}
& \mathrm{F}_{\mathrm{s}} \hat{\mathrm{l}}_{\mathrm{L}}(\mathrm{s})+\mathrm{I}_{\mathrm{L}} \hat{\mathrm{f}}_{\mathrm{s}}(\mathrm{s})=\frac{\mathrm{D}_{1}}{2 \mathrm{~L}}\left(\mathrm{~V}_{\mathrm{c}} \widehat{\mathrm{d}}_{2}(\mathrm{~s})+\left(\mathrm{D}_{1}+\mathrm{D}_{2}\right) \hat{\mathrm{v}}_{\mathrm{c}}(\mathrm{s})\right) \\
& \mathrm{F}_{\mathrm{s}} \hat{\mathrm{l}}_{\mathrm{L}}(\mathrm{s})=-\mathrm{I}_{\mathrm{L}} \hat{\mathrm{f}}_{\mathrm{s}}(\mathrm{s})+\frac{\mathrm{D}_{1}}{2 \mathrm{~L}}\left(\mathrm{~V}_{\mathrm{c}} \widehat{\mathrm{d}}_{2}(\mathrm{~s})+\left(\mathrm{D}_{1}+\mathrm{D}_{2}\right) \hat{\mathrm{v}}_{\mathrm{c}}(\mathrm{s})\right)(
\end{aligned}
$$

After rearranging terms,

$$
\hat{\mathrm{l}}_{\mathrm{L}}(\mathrm{s})=-\frac{\mathrm{I}_{\mathrm{L}}}{\mathrm{F}_{\mathrm{s}}} \hat{\mathrm{f}}_{\mathrm{s}}(\mathrm{s})+\frac{\mathrm{D}_{1}}{2 \mathrm{~F}_{\mathrm{s}} \mathrm{L}}\left(\mathrm{V}_{\mathrm{c}} \widehat{\mathrm{d}}_{2}(\mathrm{~s})+\left(\mathrm{D}_{1}+\mathrm{D}_{2}\right) \hat{\mathrm{v}}_{\mathrm{c}}(\mathrm{s})\right)(\mathrm{A}
$$

When applying KCL at node ' $a$ ' in Fig. A.1 under DCM mode-II operation of boost converter (duty is $\mathrm{D}_{2}$ ),

$$
\mathrm{C} \frac{\mathrm{dV}_{\mathrm{c}}}{\mathrm{dt}}=-\frac{\mathrm{v}_{\mathrm{c}}}{\mathrm{R}_{\mathrm{sa}}}-\mathrm{I}_{\mathrm{L}}=-\mathrm{I}_{\mathrm{sa}}-\mathrm{I}_{\mathrm{L}}
$$

Applying state space averaging,

$$
C \frac{d v_{c}}{d t}=\left(-\frac{v_{c}}{R_{s a}}-I_{L}\right) D_{1}+\left(-\frac{v_{c}}{R_{s a}}-I_{L}\right) D_{2}
$$


Applying small signal linearization to Eq. (A.20),

$$
\begin{gathered}
C \frac{d\left(V_{c}+\widehat{v}_{c}\right)}{d t}=\left(-\frac{\left(V_{C}+\widehat{v}_{c}\right)}{R_{s a}}-\left(I_{L}+\hat{i}_{L}\right)\right) D_{1} \\
+\left(-\frac{\left(V_{C}+\widehat{v}_{C}\right)}{R_{s a}}-\left(I_{L}+\hat{\mathrm{l}}_{L}\right)\right)\left(D_{2}+\widehat{d}_{2}\right)
\end{gathered}
$$

After Laplace Transformation,

$$
\begin{aligned}
& s C \hat{v}_{c}(s)=-\frac{D_{1}}{R_{s a}} \hat{v}_{c}(s)-D_{1} \hat{l}_{L}(s)-\frac{D_{2}}{R_{s a}} \hat{v}_{c}(s)-D_{2} \hat{l}_{L}(s) \\
& -\frac{V_{c}}{R_{s a}} \widehat{d}_{2}(s)-I_{L} \hat{d}_{2}(s) \\
& =-\frac{\left(D_{1}+D_{2}\right)}{R_{s a}} \hat{v}_{c}(s)-\left(D_{1}+D_{2}\right) \hat{l}_{L}(s)-\left(\frac{V_{c}}{R_{s a}}+I_{L}\right) \hat{d}_{2}(s)
\end{aligned}
$$

By substituting Eqs. (A.9) and (A.18) into Eq. (A.23), it becomes,

$$
\begin{aligned}
& \mathrm{sC} \hat{v}_{c}(s)+\frac{D_{1}+D_{2}}{R_{S a}} \hat{v}_{c}(s)= \\
& \left(\mathrm{D}_{1}+\mathrm{D}_{2}\right) \frac{\mathrm{I}_{\mathrm{L}}}{\mathrm{F}_{\mathrm{s}}} \hat{\mathrm{f}}_{\mathrm{s}}(\mathrm{s})-\left(\mathrm{D}_{1}+\mathrm{D}_{2}\right) \frac{\mathrm{D}_{1}}{2 \mathrm{LF}_{\mathrm{s}}}\left(\frac{\mathrm{V}_{\mathrm{c}}\left(\mathrm{D}_{1}+\mathrm{D}_{2}\right)}{\mathrm{V}_{\mathrm{DC}}-\mathrm{V}_{\mathrm{c}}} \hat{\mathrm{v}}_{\mathrm{c}}(\mathrm{s})+\left(\mathrm{D}_{1}+\right.\right. \\
& \left.\left.\mathrm{D}_{2}\right) \hat{\mathrm{v}}_{\mathrm{c}}(\mathrm{s})\right)-\left(\frac{\mathrm{V}_{\mathrm{c}}}{\mathrm{R}_{\mathrm{sa}}}+\mathrm{I}_{\mathrm{L}}\right)\left(\frac{\mathrm{D}_{1}+\mathrm{D}_{2}}{\mathrm{~V}_{\mathrm{DC}}-\mathrm{V}_{\mathrm{c}}}\right) \hat{\mathrm{v}}_{\mathrm{c}}(\mathrm{s})
\end{aligned}
$$

After simplification of Eq. (24), the control-to-PV voltage transfer function of the PV system can be expressed by the Eq. (A.25)

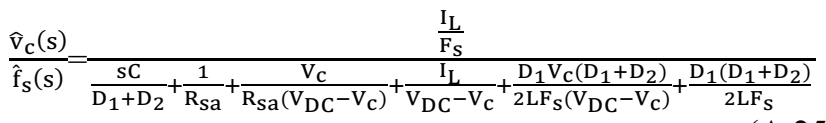

Small signal modeling of boost converter for wind generator system

When the switch is on (turn on duty $\mathrm{D}_{1}$ ), the voltage second balance equation of the boost converter can be expressed as,

$$
L_{s} \frac{d i_{w}}{d t}=e_{w}-R_{s} i_{w}
$$

When the switch is off (turn off duty $\mathrm{D}_{0}=1-\mathrm{D}_{1}$ ):

$$
L_{s} \frac{d i_{w}}{d t}=e_{w}-R_{s} i_{w}-v_{D C}
$$

Applying state-space averaging to (A.26) and (A.27),

$L_{s} \frac{d i_{w}}{d t}=\left(e_{w}-R_{s} i_{w}\right) D_{1}+\left(e_{w}-R_{s} i_{w}-v_{D C}\right)\left(1-d_{1}\right)$

$L_{s} \frac{d i_{w}}{d t}=e_{w}-R_{s} i_{w}-v_{D C}\left(1-d_{1}\right)$

Applying small signal perturbations,

$$
\begin{gathered}
\mathrm{i}_{\mathrm{w}}=\mathrm{I}_{\mathrm{w}}+\hat{\mathrm{i}}_{\mathrm{w}} \\
\mathrm{d}_{1}=\mathrm{D}_{1}+\hat{\mathrm{d}}_{1} \\
\mathrm{e}_{\mathrm{w}}=\mathrm{E}_{\mathrm{w}}+\hat{\mathrm{e}}_{\mathrm{w}} \\
\mathrm{v}_{\mathrm{DC}}=\mathrm{V}_{\mathrm{DC}}+\widehat{\mathrm{V}}_{\mathrm{DC}}
\end{gathered}
$$

Applying small signal averaging technique and linearization process to eq. (A.28) and (A.29),

$$
\begin{aligned}
L_{s} \frac{d\left(I_{w}+\hat{i}_{w}\right)}{d t}=\left(E_{w}+\hat{e}_{w}\right)-R_{s}\left(I_{w}+\hat{i}_{w}\right)- \\
\left(V_{D C}+\widehat{V}_{D C}\right)\left(1-\left(D_{1}+\widehat{d}_{1}\right)\right)
\end{aligned}
$$

Excluding all DC terms, the small signal equation of equation (A.34) becomes,

$$
\begin{aligned}
\mathrm{L}_{\mathrm{s}} \frac{\mathrm{d}\left(\hat{\mathrm{i}}_{\mathrm{w}}(\mathrm{s})\right)}{\mathrm{dt}}= & \hat{\mathrm{e}}_{\mathrm{w}}(\mathrm{s})-\mathrm{R}_{\mathrm{s}} \hat{\mathrm{i}}_{\mathrm{w}}(\mathrm{s})-\widehat{\mathrm{V}}_{\mathrm{DC}}(\mathrm{s})\left(1-\mathrm{D}_{1}\right) \\
& +\mathrm{V}_{\mathrm{DC}} \hat{\mathrm{d}}_{1}(\mathrm{~s})
\end{aligned}
$$

From equation (A.35), the control (duty ratio $\left(\mathrm{d}_{1}\right)$ ) to output current $\left(\mathrm{i}_{\mathrm{w}}\right)$ transfer function of the wind generator system can be expressed by the equation (A.36),

$$
\frac{\hat{l}_{W}(s)}{\widehat{d}_{1}(s)}=\frac{V_{D C}}{s L_{s}+R_{s}}
$$

\section{Acknowledgement}

This work was supported by "Human Resources Program in Energy Technology" of the Korea Institute of Energy Technology Evaluation and Planning (KETEP), granted financial resource from the Ministry of Trade, Industry \& Energy, Republic of Korea. (No. 20164010201010)

\section{References}

[1] Mohammad B. Shadmand and Robert S. Balog, "Multi-Objective Optimization and Design of Photovoltaic-Wind Hybrid System for Community Smart DC Micro grid," IEEE Trans. Smart Grid, vol. 5, no. 5, pp. 2635-2643, Sep. 2014.

[2] Rupesh G. Wandhare, Vivek Agarwal, "Novel Integration of a PV-Wind Energy System With Enhanced Efficiency," IEEE Trans. Power Electron., vol. 30, no. 7, pp. 3638-3649, July. 2015.

[3] A. M. Osman Haruni, Michael Negnevitsky, Md. Enamul Haque, "A Novel Operation and Control Strategy for a Standalone Hybrid Renewable Power System," IEEE Trans. Sustain. Energy, vol. 4, no. 2, pp. 402-413, Apr. 2013.

[4] Yun-Su Kim, Eung-Sang Kim, "Frequency and Voltage Control Strategy of Standalone Micro grids With High Penetration of Intermittent Renewable 
Generation Systems," IEEE Trans. Power Syst., vol. 31, no. 1, pp. 718-728, Jan. 2016.

[5] Cheng-Wei Chen, Chien-Yao Liao, Kun-Hung Chen, "Modeling and Controller Design of a Semi-isolated Multi-input Converter for a Hybrid PV/Wind Power Charger System," IEEE Trans. Power Electron., vol. 30, no. 9, pp. 4843-4853, Sep. 2015.

[6] Georgios C. Christidis, Anastasios Ch. Nanakos, Emmanuel C. Tatakis, "Hybrid Discontinuous/ Boundary Conduction Mode of Flyback Microinverter for AC-PV Modules," IEEE Trans. Power Electron., vol. 31, no. 6, pp. 4195-4205, Jun. 2016.

[7] Sachin Jain, Athiesh Kumar Thopukara, Ramsha Karampuri, "A Single-Stage Photovoltaic System for a Dual-Inverter-Fed Open-End Winding Induction Motor Drive for Pumping Applications," IEEE Trans. Power Electron., vol. 30, no. 9, pp. 4809-4818, Sept. 2015.

[8] Md. Rabiul Islam, Youguang Guo, "A HighFrequency Link Multilevel Cascaded MediumVoltage Converter for Direct Grid Integration of Renewable Energy Systems," IEEE Trans. Power Electron., vol. 29, no. 8, pp. 4167-4182, Aug. 2014.

[9] Mehdi Mosadeghy, Ruifeng Yan, Tapan Kumar Saha, "A Time-Dependent Approach to Evaluate Capacity Value of Wind and Solar PV Generation," IEEE Trans. Sustain. Energy, vol. 7, no. 1, pp. 129-138, Jan. 2016.

[10] Rajiv K. Varma, Shah Arifur Rahman, Tim Vanderheide, "New Control of PV Solar Farm as STATCOM (PV-STATCOM) for Increasing Grid Power Transmission Limits During Night and Day," IEEE Trans. Power Del., vol. 30, no. 2, pp. 755-763, Sept. 2015.

[11] Mattia Marinelli, Petr Maule, Andrea N. Hahmann, "Wind and Photovoltaic Large-Scale Regional Models for Hourly Production Evaluation," IEEE Trans. Sustain. Energy, vol. 6, no. 3, pp. 916-923, Jul. 2015.

[12] Kai Zou, Ashish P. Agalgaonkar, Kashem M. Muttaqi, "An Analytical Approach for Reliability Evaluation of Distribution Systems Containing Dispatchable and Nondispatchable Renewable DG Units," IEEE Trans. Smart Grid, vol. 5, no. 6, pp. 2657-2665, Nov. 2014.

[13] Hossein Haghighat, Bo Zeng, "Distribution System Reconfiguration Under Uncertain Load and Renewable Generation," IEEE Trans. Power Syst., vol. 31, no. 4, pp. 2666-2675, Jul. 2016.

[14] M. M. Rajan Singaravel, S. Arul Daniel, "MPPT With Single DC-DC Converter and Inverter for GridConnected Hybrid Wind-Driven PMSG-PV System," IEEE Trans. Ind. Electron., vol. 62, no. 8, pp. 48494857, Aug. 2015.

[15] Sachin Jain, S. Ramsha Karampuri, V. T. Somasekhar, "An Integrated Control Algorithm for a Single-Stage PV Pumping System Using an Open-End Winding
Induction Motor," IEEE Trans. Ind. Electron., vol. 63, no. 2, pp. 956-965, Feb. 2016.

[16] Ashraf Ahmed, Li Ran, Sol Moon, Joung-Hu Park, "A Fast PV Power Tracking Control Algorithm With Reduced Power Mode," IEEE Trans. Energy Convers., vol. 28, no. 3, pp. 565-575, Sept. 2013.

[17] Mohammed Alsayed, Mario Cacciato, Giuseppe Scarcella, "Multicriteria Optimal Sizing of Photovoltaic-Wind Turbine Grid Connected Systems," IEEE Trans. Energy Convers., vol. 28, no. 2, pp. 370-379, Jun. 2013.

[18] Ruth Domínguez, Antonio J. Conejo, "Toward Fully Renewable Electric Energy Systems," IEEE Trans. Power Syst., vol. 30, no. 1, pp. 316-326, Jan. 2015.

[19] Raji Atia, Noboru Yamada, "Sizing and Analysis of Renewable Energy and Battery Systems in Residential Microgrids," IEEE Trans. Smart Grid, vol. 7, no. 3, pp. 1204-1213, May 2016.

[20] Nan Li, Canan Uçkun, Emil M. Constantinescu, "Flexible Operation of Batteries in Power System Scheduling With Renewable Energy," IEEE Trans. Sustain. Energy, vol. 7, no. 2, pp. 685-696, Apr. 2016.

[21] Hyun-Hak Shin, Honnyong Cha, "Novel SinglePhase PWM AC-AC Converters Solving Commutation Problem Using Switching Cell Structure and Coupled Inductor," IEEE Trans. Power Electron., vol. 30, no. 4, pp. 2137-2147, Apr. 2015.

[22] Bishwajit Saha, Rae-Young Kim, "High Power Density Series Resonant Inverter Using an Auxiliary Switched Capacitor Cell for Induction Heating Applications," IEEE Trans. Power Electron., vol. 29, no. 4, pp. 1909-1918, Apr. 2014.

[23] Daniel Thenathayalan, Joung-Hu Park, "Wide-AirGap Transformer Model for the Design-Oriented Analysis of Contactless Power Converters," IEEE Trans. Ind. Electron., vol. 62, no. 10, pp. 6345-6359, Oct. 2015.

[24] Daniel Thenathayalan, Chun-gu Lee, Joung-Hu Park, "High-Order Resonant Converter Topology With Extremely Low-Coupling Contactless Transformers," IEEE Trans. Power Electron., vol. 31, no. 3, pp. 2347-2361, Mar. 2016.

[25] H. M. Ryu, "Highly efficient AC-DC converter for small wind power generators," Journal of Power Electronics, vol. 11, no. 2, pp. 188-193, Mar. 2011.

[26] Choi Byung-Min, "Multiple MPPT Control Method for PV-Wind Power Conditioning System" M.A. thesis, Soongsil University, Seoul, Korea, 2016.

[27] Yu-Kang Lo, Jing-Yuan Lin, Sheng-Yuan Ou, "Switching-Frequency Control for Regulated Discontinuous-Conduction-Mode Boost Rectifiers," IEEE Trans. Ind. Electron., vol. 54, no. 2, pp. 760-768, Apr. 2007.

[28] Tai-Sik Hwang, Sung-Yeul Park, "Seamless Boost Converter Control Under the Critical Boundary Condition for a Fuel Cell Power Conditioning 
System," IEEE Trans. Power Electron., vol. 27, no. 8, pp. 3616-3626, Aug. 2012.

[29] M. Lydia, A. Immanuel Selvakumar, S. Suresh Kumar, "Advanced Algorithms for Wind Turbine Power Curve Modeling," IEEE Trans. Sustain. Energy, vol. 4, no. 3, pp. 827-835, Jul. 2013.

[30] Fernando A. Inthamoussou, Fernando D. Bianchi, Hernan De Battista, "LPV Wind Turbine Control With Anti-Windup Features Covering the Complete Wind Speed Range," IEEE Trans. Energy Convers., vol. 29, no. 1, pp. 259-266, Mar. 2014.

[31] Milana Trifkovic, Mehdi Sheikhzadeh, Khaled Nigim, "Modeling and Control of a Renewable Hybrid Energy System With Hydrogen Storage," IEEE Trans. Control Syst. Technol., vol. 22, no. 1, pp. 169-179, Jan. 2014.

[32] Do-Hyun Kim, Hyun-Woo Kim, Joung-Hu Park, and Hee-Jong Jeon, "High Efficiency High-Step-up Single-ended DC-DC Converter with Small Output Voltage Ripple," Journal of Power Electronics, vol. 15, no. 6, pp. 1468-1479, November 2015.

Daniel Thenathayalan received his M.S. degree from Soongsil University, Seoul, Korea, in 2013, where he is presently working towards his Ph.D degree.

Ashraf Ahmed is presently working as an Assistant Professor at Soongsil University, Seoul, Korea, and as a Researcher in the Desert Research Center, Cairo, Egypt.

Byung-Min Choi received the M.S. degree from the Department of Electrical Engineering, Soongsil University, Seoul, Korea, in 2015,

Jeong-Hyun Park received the B.S. degree from the Department of Electrical Engineering, Soongsil University, Seoul, Korea, in 2014, where he is currently working toward the Master's degree.

Joung-Hu Park is currently working as an Associate Professor at Soongsil University, Seoul, Korea. 